\title{
Growth performance of broiler birds fed varying dietary levels of artemisia annua
} (sweet wormwood)

*Ani, A. O., Iyida, D. U., Ogwuegbu, M. C., Osita, C. O. and Edeh, H. O. Department of Animal Science, University of Nigeria Nsukka, Nigeria

Abstract

*Corresponding author: augustine.ani@unn.edu.ng

The study was conducted to investigate the growth performance of broiler birds fed varying dietary levels of Artemisia annua. A total of 90 broiler chickens (Arbor Acre strain) were used. The study lasted for eight weeks. At the starter phase, 90 fourteen-day old broiler chicks were randomly allocated to five groups and fed starter diets containing five levels of $A$. annua $(0,50,100,150$ and $200 \mathrm{~g}$ per $\mathrm{kg}$ of diet, respectively). At the finisher phase, 90 forty-two-day old finisher broilers were randomly allocated to five groups and fed finisher diets containing five levels of A. annua (0, 50, 100, 150 and $200 \mathrm{~g}$ per $\mathrm{kg}$ of diet, respectively). Each group was replicated three times with six birds per replicate in a completely randomized design. Parameter measured includes body weight, average daily feed intake, feed conversion ratio and protein efficiency ratio. The result of the proximate composition showed that Artemisia annua leaf meal contained $10.50 \%$ moisture, $26.27 \%$ crude protein, $5.00 \%$ crude fibre, $9.60 \%$ ash, $2.00 \%$ ether extract and $46.63 \%$ nitrogen-free extract. The result showed that at the starter phase, the inclusion of varying levels of $A$. annua in the starter diets had significant $(p<0.05)$ effect on the final body weight $(F B W)$ of birds. Birds fed diet 2 (diet containing $50 \mathrm{~g}$ of $\mathrm{A}$. annua per $\mathrm{kg}$ diet) had significantly $(p<0.05)$ higher final body weight $(F B W)$ value $(1115.00 \mathrm{~g})$ than those fed diet 5 (diet containing $200 \mathrm{~g}$ of A. annua per $\mathrm{kg}$ of diet) which had FBW value of $915.00 \mathrm{~g}$. Dietary treatments had no significant $(p>0.05)$ effect on average daily feed intake (ADFI), total weight gain (TWG), average daily weight gain $(A D W G)$, feed conversion ratio (FCR) and protein efficient ratio(PER) of the birds. At the finisher phase, significant $(p<0.05)$ differences existed among treatments in $A D W G, T W G$, $F B W$ and ADFI. Birds fed diet containing $50 \mathrm{~g} \mathrm{~A}$. annua per $\mathrm{kg}$ diet had significantly $(p<$ $0.05)$ higher $A D W G, T W G$ and FWG values than those fed the control diet. However, no significant $(p>0.05)$ differences existed among treatments in FCR and PER. It is concluded that A. annua leaf meal can be included in the diet of starter and finisher broilers at $200 \mathrm{~g}$ per $\mathrm{kg}$ of diet without any deleterious effect on the growth performance of birds.

Keywords: Artemisia annua, broilers, diets, growth performance

\section{Introduction}

Animal protein requirement in developing countries has become critical due to a disproportionate growth in human population relative to livestock production. Enhancing poultry production is recognized as one of the viable means of meeting the increasing demand for animal protein globally. Enzymes and antibiotics in feed, for example, which serve as aids to nutrition and are widely used in intensive livestock production systems in developed societies to improve the digestibility of feeds and utilisation of nutrients, are not available to many resource-poor farmers in developing countries. Besides, the fact that some serious disadvantages associated with synthetic drugs such as those used in the treatment of helminthosis and coccidiosis during poultry production have become evident, including resistance and the presence of traces of these drugs at later ends of the food chain due to their indiscriminate use has given farmers further encouragement to seek natural products such as Artemisia annua. Artemisia annua 


\section{Growth performance of broiler birds fed varying dietary levels of artemisia annua}

(sweet wormwood) is a vigorous growing annual weedy herb, usually singlestemmed, reaching up to $2-3 \mathrm{~m}$ in height (Ferreira and Janick, 2002). The plant produces a beautiful portfolio of bioactive compounds including flavonoids, coumarins, steroids, phenolics, purines, lipids, aliphatic compounds, monoterpenoids, triterpenoids and sesquiterpenoids (Bhakuni et al., 2001; Brisibe et al., 2009). A. Annua and its semi synthetically prepared derivatives such as dihydroartemisinin, artesunate, artemether, arteether, and artemisinin have also displayed unique pharmacological activities against a wide range of parasitic organisms including Enterobacter and Klebsiella species, Streptococcus faecalis, Staphylococcus aureus, Shigella dysenteriae, Escherichia coli and Pneumocystis carinii (Chen et al., 1994), an opportunistic pathogen which causes pneumonia in AIDS and other immunecompromised patients. Undoubtedly, there is growing interest in natural sources of nutrients and health-promoting compounds. Green plants generally are known as sources of bioactive compounds with potential use as antioxidants and immune system modulators. The present study was therefore, conducted to evaluate the growth performance of broilers fed varying dietary levels of Artemisia annua (sweet wormwood).

\section{Materials and methods}

The study was conducted at the Department of Animal Science Teaching and Research Farm, University of Nigeria, Nsukka. At the starter phase, a total of 90 fourteen-day old broiler chicks (Arbor Acre strain) were randomly divided into five treatment groups of 18 birds each. The groups were randomly assigned to five experimental diets containing $0 \mathrm{~g}, 50 \mathrm{~g}, 100 \mathrm{~g}, 150 \mathrm{~g}$ and $200 \mathrm{~g}$, respectively of $A$. annua per $\mathrm{kg}$ diet in a completely randomized design (CRD). At the end of the starter period, the 90 birds (forty-two-day old finisher broilers) were assigned to five experimental diets containing $0 \mathrm{~g}, 50 \mathrm{~g}, 100 \mathrm{~g}, 150 \mathrm{~g}$ and $200 \mathrm{~g}$, respectively of $A$. annua per $\mathrm{kg}$ diet. The percentage compositions of the starter and finisher diets are shown in Tables 1 and 2.

Each treatment group was replicated three times with six birds per replicate and housed in $2.6 \mathrm{~m} \times 3 \mathrm{~m}$ deep litter pens of fresh wood shavings. The birds were properly vaccinated as and when due. Feed and water were offered ad libitum every morning, from7.00am to 8.00am during the eight weeks experimental period. The weight of the feed offered minus the weight of the left over feed was recorded as the daily feed intake. The birds were weighed at the beginning of the experiment to determine their initial body weights, and subsequently on weekly basis to determine their live body weights. The birds were also weighed at the end of the experiment to determine their final body weights.

\section{Proximate analysis}

Experimental diets and the test ingredient (A. annua) were subjected to proximate analysis according to AOAC (2006).

\section{Statistical analysis}

Data collected were subjected to analysis of variance for completely randomized design as described by Steel and Torrie (1980) and according to the procedure for a one-way analysis in a completely randomized design using a Stat Graphic Computer Package (SPSS, 2007) Model. Significantly different means were separated using Duncan's New Multiple Range Test (Duncan, 1955).

\section{Results and discussion \\ Proximate composition of Artemisia annua leaf meal and experimental diets}

The proximate compositions of the starter and finisher broiler diets are presented in 
Table 1: Percentage composition of starter diets

Dietary levels of Artemisia annua leaf meal(g/kg diet)

\begin{tabular}{lccccc} 
& $\mathbf{0}$ & $\mathbf{5 0}$ & $\mathbf{1 0 0}$ & $\mathbf{1 5 0}$ & $\mathbf{2 0 0}$ \\
\hline Ingredients/Diets & $\mathbf{1}$ & $\mathbf{2}$ & $\mathbf{3}$ & $\mathbf{4}$ & $\mathbf{5}$ \\
\hline Maize & 29.60 & 29.60 & 29.60 & 29.60 & 29.60 \\
Wheat offal & 14.00 & 13.95 & 13.90 & 13.85 & 13.80 \\
Soya bean meal & 16.60 & 16.60 & 16.60 & 16.60 & 16.60 \\
Groundnut cake & 16.80 & 16.80 & 16.80 & 16.80 & 16.80 \\
P.K. Cake & 15.00 & 15.00 & 15.00 & 15.00 & 15.00 \\
Fish meal & 3.0 & 3.0 & 3.0 & 3.0 & 3.0 \\
Artemisia annua & 0.00 & 0.05 & 0.10 & 0.15 & 0.20 \\
Bone meal & 4.00 & 4.00 & 4.00 & 4.00 & 4.00 \\
Salt & 0.25 & 0.25 & 0.25 & 0.25 & 0.25 \\
Methiomine & 0.25 & 0.25 & 0.25 & 0.25 & 0.25 \\
Lysine & 0.25 & 0.25 & 0.25 & 0.25 & 0.25 \\
Vit. Min. Premix* & 0.25 & 0.25 & 0.25 & 0.25 & 0.25 \\
Total & 100.00 & 100.00 & 100.00 & 100.00 & 100.00 \\
Calculated Analysis: & & & & & \\
Crude Protein (\%) & 24.02 & 24.02 & 24.03 & 24.04 & 24.04 \\
Crude fibre (\%) & 6.00 & 6.04 & 6.04 & 6.04 & 6.03 \\
Energy (Kcal of ME/kg) & 2,859 & 2,862 & 2,956 & 3,004 & 3,053 \\
\hline
\end{tabular}

Vit $\mathrm{A}-10,000.00$ iu., $\mathrm{D}_{3}-2,000$ iu., $\mathrm{B}_{1}-0.75 \mathrm{~g} ., \mathrm{B}_{2}-5 \mathrm{~g}$. , Nicotinic acid $-25 \mathrm{~g}$., Calcium pantothanate $12.5 \mathrm{~g} ., \mathrm{B}_{1} 2-0.015 \mathrm{~g}$., $\mathrm{K}_{3}-2.5 \mathrm{~g}$., E-25g., Biotin - 0.050g., Folic acid -1g., Manganese 64g., Choline chloride 250g., Cobalt-0.8g., Copper 8g., Manganese 64g., Iron -32G., Zn-40g., Iodine-0.8g., Flavomycin-100g., Spiramycin 5g., Dl-methionine-50g, Selenium 0.6g., Lysine 120g., BA

Table 2: Percentage composition of finisher diets

\begin{tabular}{|c|c|c|c|c|c|}
\hline & \multicolumn{5}{|c|}{ Dietary levels of Artemisia annua leaf meal(g / kg diet) } \\
\hline & $\mathbf{0}$ & $\mathbf{5 0}$ & 100 & 150 & 200 \\
\hline Ingredients/Diets & 1 & 2 & 3 & 4 & 5 \\
\hline Maize & 38.00 & 38.00 & 38.00 & 38.00 & 38.00 \\
\hline Wheat offal & 16.00 & 15.95 & 15.90 & 15.85 & 15.80 \\
\hline Soya bean meal & 10.00 & 10.00 & 10.00 & 10.00 & 10.00 \\
\hline Groundnut cake & 12.00 & 12.00 & 12.00 & 12.00 & 12.00 \\
\hline Palm kernel cake & 17.00 & 17.00 & 17.00 & 17.00 & 17.00 \\
\hline Fish meal & 2.00 & 2.00 & 2.00 & 2.00 & 2.00 \\
\hline Artemisia annua & 0.00 & 0.05 & 0.10 & 0.15 & 0.20 \\
\hline Bone meal & 4.00 & 4.00 & 4.00 & 4.00 & 4.00 \\
\hline Salt & 0.25 & 0.25 & 0.25 & 0.25 & 0.25 \\
\hline Methionie & 0.25 & 0.25 & 0.25 & 0.25 & 0.25 \\
\hline Lysine & 0.25 & 0.25 & 0.25 & 0.25 & 0.25 \\
\hline Vit. M. P. & 0.25 & 0.25 & 0.25 & 0.25 & 0.25 \\
\hline Total & 100.00 & 100.00 & 100.00 & 100.00 & 100.00 \\
\hline Calculated Analysis: & & & & & \\
\hline Crude Protein $(\%)$ & 20.02 & 20.02 & 20.03 & 20.04 & 20.04 \\
\hline Crude fibre $(\%)$ & 5.90 & 5.90 & 5.89 & 5.89 & 5.89 \\
\hline Energy (Kcal of ME/kg) & 2,900 & 2,900 & 2,982 & 3,031 & 3,079 \\
\hline
\end{tabular}




\section{Growth performance of broiler birds fed varying dietary levels of artemisia annua}

Tables 3 and 4, respectively. The result of the proximate composition showed that Artemisia annua leaf meal contained $10.50 \%$ moisture, $26.27 \%$ crude protein, $5.00 \%$ crude fibre, $9.60 \%$ ash, $2.00 \%$ ether extract and $46.63 \%$ nitrogen-free extract. The CP value $(26.27 \%)$ obtained in the present study is slightly lower than the value $(27.1 \%)$ reported by Brisibe et al. (2009) and greater than the value (20.3\%) reported by Esmaeili et al. (2009). The value for ash content $(9.60 \%)$ agrees with that $(9.6 \%)$ reported by Brisibe et al. (2009) but disagrees with the values $(7.5 \%$ and $10.26 \%$ ) reported by Iqbal et al. (2012) and Brisibe et al. (2008), respectively. The variation in proximate values may be attributed to environmental conditions and stages of plant growth (Khudsar et al., 2004; Zhang et al. (2004; Aftab et al., 2010; Yekuan et al., 2010).

Table 3: Proximate composition of the starter diets

\begin{tabular}{lccccc}
\hline & \multicolumn{5}{c}{ Dietary levels of Artemisia annua leaf meal(g/kg diet) } \\
Proximate components (\%) & 0 & 50 & 100 & 150 & 200 \\
\hline Dry matter & 91.50 & 90.50 & 91.50 & 89.00 & 91.00 \\
Crude protein & 24.01 & 24.08 & 24.04 & 24.03 & 24.09 \\
Crude fibre & 4.50 & 5.00 & 5.50 & 6.00 & 6.50 \\
Ash & 5.50 & 7.80 & 6.00 & 6.80 & 7.50 \\
Ether extract & 2.50 & 1.50 & 3.00 & 2.50 & 3.00 \\
Nitrogen-free extract & 54.99 & 52.12 & 52.96 & 49.67 & 58.91 \\
\hline
\end{tabular}

Table 4: Proximate composition of the finisher diets

\begin{tabular}{lccccc}
\hline & \multicolumn{5}{c}{ Dietary levels of Artemisia annua leaf meal(g/kg diet) } \\
Proximate components (\%) & 0 & 50 & 100 & 150 & 200 \\
\hline Dry matter & 90.00 & 91.50 & 90.5 & 91.50 & 90.00 \\
Crude protein & 20.08 & 20.02 & 20.05 & 20.03 & 20.05 \\
Crude fibre & 5.50 & 6.00 & 6.50 & 6.80 & 6.90 \\
Ash & 7.80 & 8.30 & 8.30 & 8.30 & 7.30 \\
Ether extract & 3.50 & 2.50 & 3.50 & 3.50 & 3.50 \\
Nitrogen-free extract & 53.12 & 63.18 & 61.65 & 61.37 & 62.25 \\
\hline
\end{tabular}

Performance of starter broilers fed diets containing varying levels of $A$. annua Table 5 shows the performance characteristics of starter broilers fed diets containing varying levels of A. Annua. The effects of treatments on final body weight were significant $(\mathrm{p}<0.05)$.

Table 5: Growth performance of starter broilers fed diets containing varying levels of Artemisia annua leaf meal

\begin{tabular}{lcccccc}
\hline & \multicolumn{7}{c}{ Dietary levels of Artemisia annua leaf meal(g/kg diet) } \\
& $\mathbf{0}$ & $\mathbf{5 0}$ & $\mathbf{1 0 0}$ & $\mathbf{1 5 0}$ & $\mathbf{2 0 0}$ \\
\hline Parameters/Diets & $\mathbf{1}$ & $\mathbf{2}$ & $\mathbf{3}$ & $\mathbf{4}$ & $\mathbf{5}$ & SEM \\
\hline Initial body weight $(\mathrm{g})$ & 544.17 & 522.50 & 485.00 & 515.00 & 521.67 & 13.48 \\
Final body weight(g) & $1046.70^{\mathrm{ab}}$ & $1115.00^{\mathrm{a}}$ & $1023.30^{\mathrm{ab}}$ & $950.00^{\mathrm{ab}}$ & $915.00^{\mathrm{b}}$ & 28.16 \\
Total weight gain $(\mathrm{g})$ & 502.50 & 592.50 & 538.33 & 435.00 & 393.33 & 31.93 \\
Average daily weight & 27.69 & 29.33 & 27.62 & 27.44 & 26.52 & 0.43 \\
gain (g) & & & & & \\
Average daily feed & 77.62 & 79.46 & 79.44 & 76.33 & 70.71 & 1.35 \\
intake (g) & & & & & \\
Feed conversion ratio & 2.81 & 2.71 & 2.88 & 2.79 & 5.39 & 0.52 \\
Protein efficiency ratio & 1.49 & 1.55 & 1.45 & 1.50 & 1.57 & 0.03 \\
\hline
\end{tabular}




\section{Ani, Iyida, Ogwuegbu,Osita and Edeh}

Birds fed diet 2 (diet containing $50 \mathrm{~g}$ of $A$. annua per $\mathrm{kg}$ diet) had significantly $(\mathrm{p}<0.05)$ higher final body weight $(\mathrm{FBW})$ value $(1115.00 \mathrm{~g})$ than those fed diet 5 (diet containing $200 \mathrm{~g}$ of $A$. annua per $\mathrm{kg}$ of diet) which had FBW value of $915.00 \mathrm{~g}$. Birds fed diets 1, 3,4 and 5 (Diets containing $0 \mathrm{~g}$, $100 \mathrm{~g}, 150 \mathrm{~g}$ and $200 \mathrm{~g}$, respectively of $A$. annua per $\mathrm{kg}$ of diet) had comparable FBW values $(1046.70 \mathrm{~g}, 1023.30 \mathrm{~g}, 950.00 \mathrm{~g}$ and $915 \mathrm{~g}$, respectively). Birds fed diets 1, 2, 3 and 4 (Diets containing $0 \mathrm{~g}, 50 \mathrm{~g}, 100 \mathrm{~g}$ and $150 \mathrm{~g}$, respectively of $A$. annua per $\mathrm{kg}$ diet) also had comparable FBW values (1046.70g, 1115.00g, 1023.30g, and $950.00 \mathrm{~g}$, respectively). There were nonsignificant $(\mathrm{p}>0.05)$ differences between the treatments in average daily feed intake, total weight gain, average daily weight gain, feed conversion ratio and protein efficiency ratio. As shown in Table 5, the inclusion of varying levels of $A$. annua $(50 \mathrm{~g}, 100,150 \mathrm{~g}$ and $200 \mathrm{~g} / \mathrm{kg}$, respectively) in the broiler starter diets had no significant $(\mathrm{p}>0.05)$ effect on daily feed intake, total weight gain, average daily weight gain, feed conversion ratio and protein efficient ratio of the birds. This tends to suggest that A. Annua leaf meal can be included in broiler starter diet at $200 \mathrm{~g}$ per $\mathrm{kg}$ of diet without adverse effects on broiler performance. This agrees with the report of Allen et al. (1997). It is likely that Artemisinin, the main bioactive compound in the herb, $A$. annua enhanced the performance of the birds. Artemisinin, the bioactive compound in A. Annua leaf meal has a beneficial effect on the gut microbiota. It has immunomodulatory and antioxidant properties and these can result in improvement of production and growth performances (Sugiharto, 2014).

Performance of finisher broilers fed diets containing varying levels of A. Annua Table 6 shows the data on the performance of finisher broilers fed diets containing varying levels of A. Annua.

Table 6: Growth performance of finisher broilers fed diets containing varying levels of Artemisia annua leaf meal

\begin{tabular}{|c|c|c|c|c|c|c|}
\hline & \multicolumn{6}{|c|}{ Dietary levels of Artemisia аппиа leaf meal(g $/ \mathrm{kg}$ diet) } \\
\hline & $\mathbf{0}$ & 50 & 100 & 150 & 200 & \\
\hline Parameters/Diets & 1 & 2 & 3 & 4 & 5 & SEM \\
\hline Final body weight(g) & $2103.30^{b}$ & $2738.30^{\mathrm{a}}$ & $2295.80^{\mathrm{ab}}$ & $2291.50^{\mathrm{ab}}$ & $1868.80^{b}$ & 93.91 \\
\hline Total weight gain $(\mathrm{g})$ & $1056.70^{b}$ & $1623.30^{\mathrm{a}}$ & $1272.50^{\mathrm{ab}}$ & $1336.50^{\mathrm{ab}}$ & $966.42^{\mathrm{b}}$ & 79.62 \\
\hline $\begin{array}{l}\text { Average daily weight } \\
\text { gain }(\mathrm{g})\end{array}$ & $37.93^{\mathrm{b}}$ & $57.97^{\mathrm{a}}$ & $45.47^{\mathrm{ab}}$ & $47.70^{\mathrm{ab}}$ & $34.51^{b}$ & 2.31 \\
\hline $\begin{array}{l}\text { Average daily feed } \\
\text { intake }(\mathrm{g})\end{array}$ & $145.43^{\mathrm{a}}$ & $160.32^{\mathrm{a}}$ & $161.15^{\mathrm{a}}$ & $144.95^{\mathrm{a}}$ & $128.54^{\mathrm{b}}$ & 3.69 \\
\hline Feed conversion ratio & 4.13 & 2.77 & 3.60 & 3.10 & 3.76 & 0.21 \\
\hline Protein efficiency ratio & 1.13 & 1.47 & 1.17 & 1.37 & 1.14 & 0.06 \\
\hline
\end{tabular}

Significant $(p<0.05)$ differences existed among treatments in final body weight (FBW), total weight gain (TWG), average daily weight gain (ADWG) and average daily feed intake (ADFI). Birds fed diet containing $50 \mathrm{~g}$ of $A$. annua per $\mathrm{kg}$ diet (treatment2) had significantly $(\mathrm{p}<0.05)$ higher FBW, TWG and ADWG and ADFI values $(2738.30,1623.30$ and $57.97 \mathrm{~g}$, respectively) than the FBW, TWG and ADWG values $(2103.30,1056.70$ and $37.93 \mathrm{~g}$, respectively) of birds fed the control diet. Birds fed diets 1, 3, 4 and 5 had similar $(p>0.05)$ FBW, TWG and ADWG values. Birds fed diets containing 50, 100 and $150 \mathrm{~g}$ of $A$. апnиа per $\mathrm{kg}$ diet 


\section{Growth performance of broiler birds fed varying dietary levels of artemisia annua}

had similar ADFI values with those fed the control diet and these were significantly ( $p$ $<0.05)$ higher than the ADFI value (128.54 g) of birds fed diet containing $200 \mathrm{~g}$ of $A$. annua per $\mathrm{kg}$ diet (treatment 5). There were no significant $(\mathrm{p}>0.05)$ differences among treatments in feed conversion ratio and protein efficiency ratio. As shown in Table 6 , the growth rate of birds fed diets containing varying levels of A.annua improved significantly compared to those fed the control diet. The significant improvement could be attributed to the essential minerals and vitamins in the test ingredient. It is interesting to note that Artemisinin, the main bioactive compound of the herb A.annua has been extensively studied for its effects on performance of broiler chickens and it has been shown that the active compound enhances the growth of broilers (Brisibe et al., 2009). As shown in Table 6, the mean ADFI value of birds fed diet containing (200g of A.annua per $\mathrm{kg}$ diet) was $128.54 \mathrm{~g}$ and this was lower than that of birds fed the control diet. This could be attributed to the high inclusion of A.annua in the diet. This probably might have imparted a bitter taste on the feed and consequently reduced feed intake (Yeka and Harris, 2010). Considering the observed improvement in growth performance of birds at all the inclusion levels of dried A. annua leaves in the broiler diets, it could be inferred that the diets were acceptable to the birds and that $A$. annua leaves can be used in compounding feed rations for broiler birds (Mojarad et al., 2005).

\section{Conclusion}

The study showed that A. annua leaf meal can be included in the diet of starter broilers at $200 \mathrm{~g}$ per $\mathrm{kg}$ of diet without any deleterious effect on the growth performance of birds.

\section{References}

Aftab, T., Khan, M. A., Idrees, M., Naeem, M., Ram, M. 2010. Boron induced oxidative stress, antioxidant defence response and changes in artemisinin content in A. annua L. J. Agron. Crop Sci. 5 (3), 203-256.

Allen, M. J., Drummond, J. A. and Moffat, K. G. 1997. Analysis of a P[GAL4] enhancer-trap expressed in the giant fibre system. Doe, Hall: 18. (Export to RIS).

AOAC 2006. Official Methods of Analysis. $18^{\text {th }}$ Ed., Association of Official Analytical Chemists, Washington, D.C

Bhakuni, R. S., Jain, D. C. Sharma, R. P. and Kumar, S. 2001. Secondary metabolites of Artemisia annua and their biological activity. Curr. Sci., 80: 35-48.

Brisibe, E. A, Umoren, U. E., Brisibe, F., Magalhaes, P. M., Ferreira, J. F. S., Luthria, D., Wu X. and Prior, R. L. 2009 . Nutritional characterization and antioxidant capacity of different tissues of Artemisia annua L. Food Chem. 115: 1240-1246.

Brisibe, E. A., Umoren, U. E., Owai, P.U. and Brisibe, F. 2008. Dietary inclusion of dried Artemisia annua leaves for management of coccidiosis and growth enhancement in chickens. African Journal of Biotechnology 7:4083-4092.

Chen, W., Mahlke, S., Warter, N., Anik, S. and Hwu, W. 1994. Profile assisted instruction scheduling. Int. J. of Parallel Programming, 22(2):151-181.

Duncan, D. B. 1955. New Multiple Range Test,Biometrics 11:1-42.

Esmaeili F., Sepehri G., Moshtaghi- 


\section{Ani, Iyida, Ogwuegbu,Osita and Edeh}

Kashanian, G. R., Khaksari, M., Salari N. and Sepehri, E. 2009. The effect of acute administration of Artemisia Persia extracts on arterial blood pressure and heart rate in rats. Am. J. Appl. Sci. 6: 843847.

Ferreira, J. F. S. and Janick, J. 2002. Production of Artemisinin from in vitro cultures of Artemisia annua L., Biotechnology in Agriculture and Forestry Vol. 51, SpringerVerlag, Berlin, Germany, p. 1-12.

Iqbal, S., Younas, U., Chan, K. W., Sarfraz, R. A. and Uddin, M. K. 2012. Proximate composition and antioxidant potential of leaves from three varieties of Mulberry (Morus sp.): a comparative study. International journal of molecular sciences.13(6):6651-64.

Khudsar, T., Mahmooduzzafar, M. I. and Sairam, R. K. 2004. Zn-induced changes in morpho-physiological and biochemical parameters in Artemisia annua. Biol. Plant., 48: 255-260.

Mojarad, T. B., Roghani, M. and Zare, N. 2005. Effect of subchronic administration of aqueous Artemisia annua extract on $\alpha 1$ adrenoceptor agonist-induced contraction of isolated aorta in rat. Iran. Biochem. J. 9: 57-62.

Sen, S., Ingale, S. L., Kim, Y. W., Kim, J.S., Lohakare, J.D., Kim, E. K., Kim, H. S., Ryu, M. H., Kwon, I. K., and Chae, B. J. 2012. Effect of supplementation of Bacillus subtilis LS 1-2 to broiler diets on growth performance, nutrient retention, caecal microbiology and small intestinal morphology. Research in Veterinary Science. 93, 264-268.

SPSS.Com. 2007 . IB M ${ }^{(R)} \mathrm{SPS} \mathrm{S}^{(\mathrm{R})}$
Advantage for Microsoft

${ }^{(\mathrm{R})}$ IBM.Corporation 2010,IBM

$\begin{array}{lllllllllll}\mathrm{C} & \mathrm{o} & \mathrm{r} & \mathrm{p} & \mathrm{o} & \mathrm{r} & \mathrm{a} & \mathrm{t} & \mathrm{i} & \mathrm{o} & \mathrm{n}\end{array}$

Route, 100,Somers,N4. 10589.

Steel, R. G. D. and Torrie, J. H. 1980.

Principles and procedures of statistics. A biometric approach ( $2^{\text {nd }}$ ed.). McGraw-Hill Publishers, New York.

Sugiharto, S. 2014. Role of nutraceuticals in gut health and growth performance of poultry. Journal of the Saudi Society of Agricultural $\mathrm{S}$ c i e n c e s. doi:10.1016/j.jssas.2014.06.001.

Yeka, A. and Harris, J. C. 2010. Treating uncomplicated malaria in children: comparing artemisinin-based combination therapies. Current Opinion in Pediatrics 22:798-803.

Yekuan,W., Longyun, L., Ma, P., Xiaoli, W., Fangyi, L., Zhixue, W. 2010. Effects of zinc, manganese and boron on artemisinin and yields of A r t e m is i a a n n u a J.Chin.Mater.Med.35(3),275-27.

Zhang X.Y., Yang, H.M and G.X. Wang, 2004. Effects of heavy metals on stomatal movements in broad bean leaves. Russ. J. Plant Physiol., 51: 464-468.

Zimroch, L., Szarek, J., Abczak, J., Konwicki, A. 2000. Effects of feed supplements on morphological pattern of internal organs in broiler chickens. ZesNaukPTZPrzHod. 49, 65-76 [in Polish].

Received: $19^{\text {th }}$ September 2018 Accepted: $21^{\text {st }}$ December, 2018 